УДК 159.99

DOI 10.11603/2411-1597.2020.4.11874

\title{
ПСИХОЛОГІЧНІ АСПЕКТИ ПАЛІАТИВНОЇ ДОПОМОГИ ХВОРИМ НА СНІД ТА ВІЛ-ІНФІКОВАНИМ
}

\author{
О. А. Полоз
}

Комунальний заклад «Олександрійський медичний фаховий коледж»

У статті йдеться про важливість психологічного аспекту паліативної допомоги хворим на СНІД та ВІЛінфікованим та способи подолання стресу і тривожності у пацієнтів із невиліковними захворюваннями.

\section{PSYCHOLOGICAL ASPECTS OF THE PALLIATIVE CARE FOR AIDS AND HIV PATIENTS}

\author{
O. A. Poloz \\ Olexandriia Medical Professional College
}

The article deals with the importance of psychological aspects of the palliative care for AIDS and HIV patients and the methods to avoid stress and anxiety in incurable patients.

Вступ. Стрімке поширення ВІЛ/СНІДу в світі призвело до виходу цього захворювання за межі суто медичних проблем.

Соціально-психологічний аспект цієї хвороби залишається найменш дослідженим. Емоційний стан ВІЛ-позитивних та їхніх близьких вимагає не менш серйозного підходу, чим фізичний. У більшості таких родин бувають важкі періоди в житті, тому при розробці заходів допомоги ВІЛ-позитивним особам необхідно надавати психологічну та соціальну підтримку як ВІЛ-інфікованим особам, так і членам їхніх сімей [4].

Основна частина. Проблема СНІДу в нашій країні надзвичайно актуальна. Україна залишається лідером у Європі за масштабами поширення ВІЛ-інфекції. За оцінками експертів UNAIDS, в Україні з ВІЛ-інфекцією живе близько 290 тис. осіб. І тільки кожен другий знає про свій діагноз. Всього з 1987 р. в Україні офіційно зареєстровано 321382 нових випадки ВІЛ-інфекції. Від СНІДу в Україні померло 46024 людини. Найбільш ураженими ВІЛ-інфекцією регіонами $\epsilon$ Дніпропетровська, Одеська, Донецька, Київська й Миколаївська області, а також м. Київ [2]. Епідемія не оминула і м. Олександрію Кіровоградської області (табл. 1).

У грудні 2016 р. відкрито сайт «Антиретровірусна терапія» на базі кабінету «Довіра» при Олександрійській міській лікарні № 1.

(с) О. А. Полоз, 2020
На 01.10.2020 р. 279 осіб отримують антиретровірусну терапію безкоштовно (за кошти Глобального фонду та державного бюджету).

Тут пацієнти мають змогу отримувати не тільки лікування, а й моральну та психологічну підтримку.

Епідемія ВІЛ-інфекції у світі зумовлює значну кількість біоетичних проблем. Люди зазнають стигматизації. Стигматизація - це динамічний процес відокремлення та приниження особи у зв'язку з наявністю якої-небуть ознаки чи захворювання - стигма (від грец. - stigma - клеймо, пляма). Це порушення загальнолюдських прав ВІЛ-інфікованої людини.

Стигматизація - це процес дискримінації ВІЛінфікованих, від якого можуть постраждати не лише самі хворі, а й їхнє найближче оточення.

Для пацієнтів та їхніх родичів дізнатися про цей діагноз означає страшний вирок, руйнування мрій і сподівань, позбавлення майбутнього [9]. Люди переживають справжнє потрясіння, шок. І як проживе людина свої останні дні залежить від нас з вами.

Допомогти у цьому важкому випробуванні покликана паліативна допомога та хоспіси.

Хоспіс забезпечує організоване надання медичної, психологічної, духовної та соціальної допомоги термінально хворим та їхнім родинам.

Хоспіс віддає перевагу якості життя, а не її тривалості, акцентує важливість фізичного і духовного 
Таблиця 1. Захворюваність на ВІл-інфекцію та СНІД у м. Олександрія Кіровоградської області (кількість мешканців - 89847 осіб)

\begin{tabular}{|c|c|c|c|c|}
\hline Роки & ВІЛ-інфіковані & Хворі на СНІД & Взято на «Д» облік & Померли \\
\hline 2015 & 221 & 131 & 51 & 14 \\
\hline 2016 & 259 & 159 & 37 & 20 \\
\hline 2017 & 267 & 143 & 47 & 17 \\
\hline 2018 & 290 & 146 & 39 & 23 \\
\hline 2019 & 289 & 148 & 51 & 19 \\
\hline На 01.10 .2020 & 281 & 139 & 27 & 20 \\
\hline
\end{tabular}

контактів між людьми тоді, коли життя підходить до завершення.

Неможливо уявити нормальне життя на фоні негативних особистих переживань і депресії, що охоплюють невиліковно хвору людину.

Хоспіси і центри паліативного лікування існують, щоб зменшити фізичний біль і емоційне страждання пацієнтів.

Особиста підтримка, спілкування, кваліфікована медична та психологічна допомога, пропоновані хоспісами і центрами паліативної допомоги, зможуть задовольнити емоційні, моральні та духовні потреби пацієнтів та близьких їм людей [8].

\section{Tипи психологічних реакцій на хворобу}

Виділяють 3 головні психологічні реакції пацієнта на захворювання: стенічна, астенічна і раціональна.

1. При стенічній реакції на захворювання у хворого $\epsilon$ активна позиція до лікування і обстеження.

2. При астенічній реакції на захворювання у пацієнтів $\epsilon$ схильність до песимізму і недовірливості, але вони відносно легше, ніж хворі зі стенічною реакцією, психологічно пристосовуються до захворювання.

3. При раціональному типі реакції має місце реальна оцінка ситуації та раціональний відхід від фрустрації.

У хоспісах створюють різні групи психологічної підтримки з навчанням саморегуляції і самопідтримки, організації психологічних тренінгів для термінальних хворих. Організовують зустрічі для сімей, в яких є хворі на СНІД.

Однією з форм роботи з ВІЛ-інфікованими може бути група взаємодопомоги - «рівний - рівному». Для психологічної підтримки в групи взаємодопомоги залучають людей, які або самі мають проблему, або їхні близькі. Учасники групи діляться власними переживаннями, порадами, що дає кожному учаснику відчуття співпереживання і взаємної підтримки, а також дозволяє зібрати практичну інформацію щодо способів подолання труднощів [1].
Головний напрямок роботи психолога - нормалізація внутрішнього стану особистості та підтримка психологічної гармонії між пацієнтом і його оточенням на всіх етапах перебігу захворювання [1, 3].

Кожна людина неповторна, тому при психологічній допомозі потрібно здійснювати індивідуальний підхід до кожного пацієнта.

\section{Загальні поради, які можуть бути корисними:}

- потрібно поважати незалежність та приватність пацієнтів, запитувати дозволу увійти до їхньої кімнати, присісти поруч із ними;

- запитати, що ви можете зробити, щоб їм було комфортніше. Багато людей соромляться просити про допомогу;

- необхідно дозволяти пацієнту виконувати якусь роботу, якщо він цього хоче. Хворі на СНІД теж хочуть бути частиною колективу;

- потрібно залучати пацієнта до спілкування з родиною, до обговорення телевізійних програм, книг, музики. Цікавитися їхньою думкою на події в світі;

- необхідно говорити на різні теми. Іноді пацієнту хочеться обговорити свою ситуацію, поговорити про хворобу [1, 3].

Враховуючи те, що у ВІЛ-інфікованих часто розвивається больовий синдром, психологічна допомога повинна бути спрямована на подолання цієї проблеми.

3 метою психокорекції застосовують в більшості випадків аутогенне тренування. Аутогенне тренування $\epsilon$ методикою, спрямованою на оволодіння навичками психічної саморегуляції.

Корисним методом у лікуванні хронічного болю в термінальних стадіях ВІЛ-інфекції може бути гіпноз.

Когнітивно-поведінкова терапія. Цей метод являє собою комбінацію поведінкової терапії з пізнавальною психологією, коли основним фактором, що визначає поведінку пацієнта, $є$ мислення.

Духовна допомога $є$ найважчою й неоднозначною. Вона залежить від широкого кола обставин: 
світогляду, системи цінностей, життєвого досвіду хворого.

Висновки. Паліативна допомога хворим на СНІД це комплексний підхід, мета якого - забезпечити максимальну якість життя пацієнта шляхом запобігання та полегшення страждань.

\section{СПИСОК ЛІТЕРАТУРИ}

1. Аспекти соціально-психологічної консультативної допомоги ВІЛ-інфікованим. - Хмельницький : ЦНТЕІ, 1999. - 12 с.

2. Баранова Н. Соціально-економічні наслідки епідемії ВІЛ/СНІДу в Україні: прогнозування, моделювання, оцінка / Н. Баранова // Україна: аспекти праці. - 2006. № 1. - С. 19-25.

3. Бойко А. М. Соціальна робота з клієнтами, інфікованими ВІЛ та хворими на СНІД : методичні рекомендації з навчального курсу для магістеріуму / А. М. Бойко ; Національний університет «Києво-Могилянська Академія» ; Ужгородський державний університет. -Ужгород : УждУ, 2000. - 64 c.

4. ВІЛ та СНІД : достовірно про проблему // Психолог: всеукраїнська газета для вчителів. - К. , 2005. - № 12. C. 1-7.

5. ВІЛ/СНІД: стратегія наступу на хворобу // Здоров'я України. - 2001. - № 2. - 28 с.

6. Заєць В. Азбука СНІДу / В. Заєць. - К. : Молодь, 1998. - 95 C.
Психологічний аспект паліативної допомоги вирішує завдання полегшення психоемоційних станів, пов'язаних із невиліковним захворюванням, подолання стресу, тривожності, депресії хворих, їхніх родичів та персоналу, залученого до надання паліативної допомоги.

7. Основные принципы лечения и помощи людям, живущим с ВИЧ/СПИДом / ВОЗ/ООН - СПИД, 8 сентября 2000 г. / Перевод: Международная организация «Врачи без границ», Украина [Электронный ресурс]. - Режим доступа : http://www.spidcentr38.com/page/club/club2. html?lang=ru.

8. Паллиативная помощь при СПИДе // Технический обзор ЮНЭЙДС. - Август, 2001. - 24 с. - (Серия ЮНЭЙдС «Примеры передового опыта»).

9. Социально-медицинское изучение патогенеза ВИЧ-инфекции / Н. Митина, В. Шаповалова, Е. Вырва, В. Шаповалов // Ліки України. - 2004. - № 7-8. - С. 90-92.

10. Тухтарова И. В. Исследование реактивной и личностной тревожности у больных с ВИЧ-инфекцией, уровень тревожности у больных ВИЧ [Электронный ресурс] / И. В. Тухтарова // Медицинская информационная сеть. - Режим доступа : http://www.medicinform. net/ psycho/psych_spec35_4.htm. 